Volume 2 Nomor 2, Desember 2019

E-ISSN : 2655-7347

\title{
ANALISIS PENCANTUMAN KLAUSULA BAKU DALAM PERJANJIAN \\ SJ TRAVEL PASS DITINJAU DARI UNDANG-UNDANG NOMOR 8 TAHUN 1999 TENTANG PERLINDUNGAN KONSUMEN
}

\author{
Dea Vania Utami \\ (Mahasiswi Program S1 Fakultas Hukum Universitas Tarumanagara) \\ (E-mail: deavaniau@gmail.com)
}

\begin{abstract}
A.M. Tri Anggraini
(Corresponding Author)

Dosen Fakultas Hukum Trisakti. Meraih Sarjana Hukum (S.H) pada Fakultas Hukum Universitas Gadjah Mada (1988), Magister Hukum (M.H) pada Fakultas Hukum Universitas Tarumanagara (1995), Doktor (Dr.) pada Fakultas Hukum Ekonomi Universitas Indonesia (2003).

(E-mail: anggraini1601@gmail.com)
\end{abstract}

\begin{abstract}
Standardized clauses have been used since the days of ancient Greece in order to ease the making of agreement. In the era of economic digital has changed many things, including the process of making an agreement. Nowadays we have assumed electronic agreement as a legal covenant. With the existence of electronic agreement, customers cannot negotiate standardized clauses on the agreement anymore. The clauses generally cause more losses rather than profit, it was caused by the traders often utilized the clauses to get more profits and deprive their responsibilities. In practice even though some regulation has become of legal protection from standardized clauses in agreements, there is still a lot agreement that have standardized clauses contradictory with the regulations. One of that agreement is Sriwijaya Air Travel Pass Agreement, which one of the clauses not suitable with the article 18 verse (1) of Law No. 8 of 1999. Which is that clauses causing some disadvantages to the customers. The standardized clause should be eliminated as it opposed with the regulations. Traders obligated to undertake the responsibility of the form of compensation to the consumers.
\end{abstract}

Keywords: Agreement, Consumers, Standardized Clause

\section{PENDAHULUAN}

\section{A. Latar Belakang}

Transportasi telah ada sejak zaman dahulu, mulai dari yang paling sederhana hingga yang paling modern seperti saat ini. Pada masyarakat tradisional transportasi dipergunakan dengan tujuan untuk mempermudah pekerjaan manusia dalam melakukan perpindahan barang, kemudian mulai mengalami pergeseran kepentingan menjadi suatu alat transportasi yang digunakan untuk mempermudah manusia dalam pergerakannya dari satu 
Volume 2 Nomor 2, Desember 2019

E-ISSN : 2655-7347

tempat ke tempat lainnya. ${ }^{1)}$ Jenis-jenis transportasi ini juga terus mengalami perkembangan dan dapat dikelompokkan menurut media atau tempat dimana transportasi melakukan pergerakan, antara lain: transportasi darat, transportasi laut/perairan, transportasi udara, dan transportasi multimoda. ${ }^{2}$ Pada masa lalu, tidak semua orang di masyarakat menggunakan transportasi, hanya kalangan-kalangan menengah ke atas yang melakukan perjalanan menggunakan alat transportasi, keadaan ini sangat bertolak belakang dengan era globalisasi

dimana hampir setiap individu masyarakat menggunakan transportasi untuk memenuhi kepentingannya.

Negara Indonesia merupakan Negara Kepulauan (Archipelagic State) terbesar di dunia, dengan jumlah penduduk menduduki peringkat keempat terbesar di dunia dengan jumlah sebanyak dua ratus enam puluh sembilan juta jiwa atau sama dengan 3,49\% dari total populasi dunia. ${ }^{3)}$ Maka tidak heran apabila permintaan konsumen akan transportasi di masyarakat Indonesia sangatlah tingi. Permintaan konsumen akan kebutuhan transportasi yang terus meningkat ini diseimbangi dengan perkembangan pesat perusahaan transportasi baik perusahaan domestik dan juga perusahaan internasional. Fenomena perkemangan ini tentu membawa dampak positif bagi para konsumen, karena memberikan kemudahan dalam menentukan pilihan jasa transportasi yang dikehendaki. Transportasi juga menjadi suatu hal yang sangat penting di Indonesia, keadaan geografis Indonesia menyebabkan tanpa adanya transportasi, maka wilayah-wilayah pedalaman akan lebih sulit dijangkau, perpindahan barang dan manusia akan membutuhkan jangka waktu lebih panjang dan akan mengeluarkan biaya yang lebih banyak.

1) Ade Anung, "Sejarah Dan Perkembangan Angkutan Umum Di Dunia," http://dishub.jabarprov.go.id/artikel/view/309.html, diakses pada 7 Agustus 2019.

2) M.Y. Jinca, Transportasi Laut Indonesia: Analisis Sistem \& Studi Kasus (Surabaya: Brilian Internasional, 2011), 13.

3) Dwi Hadya Jayani, "Jumlah Penduduk Indonesia 269 Juta Jiwa Terbesar Keempat Di Dunia," https://databoks.katadata.co.id/datapublish/2019/04/29/jumlah-penduduk-indonesia-269juta-jiwa-terbesar-keempat-dunia, diakses pada 8 Agustus 2019. 
Volume 2 Nomor 2, Desember 2019

E-ISSN : 2655-7347

Tiap pelayanan jasa transportasi ini menawarkan berbagai macam pilihan jenis transportasi dengan tingkat yang berbeda-beda kepada konsumen, dari segi pelayanan, kenyamanan, tarif, dan lain-lain. ${ }^{4)}$ Diantara seluruh jenis transportasi yang beroperasi, pesawat terbang merupakan sarana transportasi yang paling aman. ${ }^{5)}$ Pesawat merupakan sarana transportasi yang paling aman dikarenakan: ${ }^{6)}$

1. Standar untuk menjadi seorang pilot sangatlah tinggi karena harus melewati ujian dan persyaratan yang sulit dibandingkan supir mobil, bus, motor, dan supir transportasi lain.

2. Risiko kematian yang diakibatkan oleh kecelakaan pesawat terbang kemungkinannya adalah 1:9.821 sedangkan jumlah kematian akibat kecelakaan transportasi lain sangat tinggi.

3. Pesawat merupakan transportasi yang paling sedikit mengalami kecelakaan dibandingkan dengan transportasi lainnya.

Di samping tingkat keamanan pesawat yang tinggi, pesawat juga memberikan waktu cepat untuk melakukan perjalanan, menggunakan fasilitas dengan teknologi yang tinggi, dan memberikan kenyamanan dengan jaminan keselamatan. Hal-hal tersebut menjadi beberapa faktor yang membuat konsumen lebih tertarik untuk memilih pesawat menjadi alat transportasi untuk melakukan suatu perjalanan.

Di Indonesia sendiri telah ada berbagai macam maskapai penerbangan mulai dari maskapai besar hingga maskapai Low Cost Carrier (LCC). Setidaknya sudah ada hampir 30 maskapai penerbangan yang beroperasi di Indonesia, antara lain Garuda Indonesia, Citilink Airlines, Air Asia, Lion Air, Batik Air, Sriwijaya, Cathay Pacific, Etihad Airways, Qatar Airways, dan

4) Stefani Erlina Halim dan Siti Nurbaiti, "Perlindungan Hukum Terhadap Transportasi Berbasis Online Yang Menggunakan Driver Cadangan”, Jurnal Adigama, Volume 1, Nomor 2 (Oktober 2018): 3.

5) Luthfia Ayu Azanella, "Berpergian Dengan Pesawat Disebut Paling Aman: Ini Datanya," https://internasional.kompas.com/read/2019/03/11/20212381/berpergian-dengan-pesawat-disebutpaling-aman-ini-datanya?page=all, diakses tanggal 7 Oktober 2019.

6) Ibid. 
Volume 2 Nomor 2, Desember 2019

E-ISSN : 2655-7347

masih banyak lainnya. ${ }^{7)}$ Berkembang pesatnya jumlah maskapai penerbangan di Indonesia ini menimbulkan persaingan sesama maskapai penerbangan yang sangat ketat. Maka dari itu, untuk tetap dapat bertahan di dunia bisnis penerbangan tiap perusahaan membutuhkan suatu strategi pemasaran yang baik, menarik, dan kreatif untuk menarik perhatian konsumen.

Maka dari itu para pelaku usaha dituntut untuk mengembangkan ide-ide kreatif dalam melakukan pemasaran agar tidak kalah bersaing dengan pelaku usaha lainnya. Pada era globalisasi ini pemasaran atau promosi menjadi lebih mudah untuk dilakukan, hal ini disebabkan karena telah terjadi perkembangan yang sangat pesat dalam masyrakat dalam penggunaan internet.

Pemanfaatan internet yang dijadikan sebagai suatu pasar untuk memfasilitasi perdagangan barang dan/atau jasa disebut sebagai ekonomi digital. ${ }^{8)}$ Perkembangan ekonomi digital ini menjadi penghubung antara masyarakat dan para pelaku usaha yang sangat baik hal ini terlihat dari pertumbuhan nilai penjualan bisnis secara online yang meningkat $40 \%$ setiap tahunnya dengan jumlah tujuh puluh satu juta pengguna aktif smartphone di Indonesia. ${ }^{9)}$ Internet pada ekonomi digital ini menghasilkan masyarakat yang tidak hanya memanfaatkan internet untuk mencari informasi atau chatting melainkan sudah hampir melakukan segala hal melalui kecanggihan internet ini, salah satu yang sering dilakukan yaitu menggunakan e-commerce (electronic commerce). Sehingga e-commerce menjadi salah satu sarana yang memegang peran penting bagi pelaku usaha untuk melakukan pemasaran di masyarakat.

\footnotetext{
7) Bandara Soekarno-Hatta, "Daftar Nama Maskapai Penerbangan yang Beroperasi Di Indonesia," https://bandarasoekarnohatta.com/daftar-nama-maskapai-penerbangan-yangberoperasi-di-indonesia.info, diakses tanggal 7 Oktober 2019.

8) Siti Yuniarti, "Internet Dan Ekonomi Digital", https://businesslaw.binus.ac.id/2019/08/26/internet-dan-ekonomi-digital/, diakses tanggal 21 Desember 2019.

9) Menteri Komunikasi dan Informatika, "Indonesia Akan Jadi Pemain Ekonomi Digital Terbesar di Asia Tenggara", https://kominfo.go.id/index.php/content/detail/6441/Indonesia+Akan+Jadi+Pemain+Ekonomi+Dig ital+Terbesar+di+Asia+Tenggara/0/berita_satker/, diakses tanggal 7 Oktober 2019.
} 
Volume 2 Nomor 2, Desember 2019

E-ISSN : 2655-7347

Hampir seluruh maskapai penerbangan di Indonesia ini telah memanfaatkan perkembangan internet dengan melakukan pemasaran atau iklan kepada konsumen dan juga melakukan perdagangan secara online. Beberapa contoh program penawaran yang diberikan seperti: potongan harga apabila melakukan pembelian di e-commerce, cashback jika melakukan pembayaran menggunakan uang digital atau uang elektronik, cicilan $0 \%$, kerjasama dengan marketplace (aplikasi yang digunakan sebagai sarana, wadah, atau fasilitas untuk melakukan transaksi jual beli) seperti traveloka, pegipegi, tiket.com, dan masih banyak lagi. Kegiatan penjualan secara online ini membawa dampak yang sangat menguntungkan kedua belah pihak tentunya, maskapai penerbangan dapat memberikan informasi dan penawaran kepada konsumen secara efisien dan pihak konsumen pun dapat melakukan pembelian tiket penerbangan secara fleksibel.

Dalam melakukan transaksi elektronik artinya seorang konsumen mengadakan suatu perjanjian dengan pelaku usaha tanpa berada di tempat yang sama atau waktu yang sama. Pada umumnya perjanjian elektronik dilakukan dengan cara pelaku usaha memberikan penawaran melalui internet dan pada pada saat konsumen tertarik atas penawaran tersebut, akan muncul formulir tertentu sebagai tanda persetujuan konsumen atas perjanjian tersebut. Sehingga perjanjian elektronik akan secara sah terbentuk ketika konsumen memilih tombol persetujuan. Pada umumnya, dalam perjanjian elektronik seringkali telah tercantum beberapa klausula baku sehingga perjanjian dapat lebih mudah dipahami dan memberi batasan-batasan yang lebih jelas kepada konsumen dalam melakukan persetujuan terhadap perjanjian tersebut. Dalam suatu perjanjian klausula baku umumnya dituliskan dengan judul syarat dan ketentuan yang berisi beberapa aturanaturan yang ditentukan oleh pihak pelaku usaha.

Klausula baku dibuat dengan tujuan untuk memberikan kemudahan bagi para pihak yang bersangkutan dalam menerbitkan suatu perjanjian. Tetapi dengan adanya perkembangan hingga ke tahap perjanjian elektronik, umumnya pihak lain dalam perjanjian menjadi tidak memiliki kesempatan 
Volume 2 Nomor 2, Desember 2019

E-ISSN : 2655-7347

untuk melakukan negosiasi atas klausula yang dibentuk secara sepihak oleh pihak lainnya, sehingga terkadang klausula-klausula tersebut dapat menyebabkan perjanjian membuat kedudukan para pihak tidak seimbang sehingga dapat mengakibatkan kerugian pada salah satu pihak. ${ }^{10)}$ Untuk mencegah pencantuman klausula baku yang menyebabkan kerugian, Indonesia mengatur pencantuman klausula baku ini secara sistematis melalui regulasi Undang-Undang Nomor 8 Tahun 1999 tentang Perlindungan Konsumen (UUPK), dengan harapan agar pihak terkait dapat melakukan pencantuman klausula-klausula untuk mempermudah terbentuknya perjanjian tanpa memberikan kerugian kepada pihak konsumen.

Pada faktanya, meskipun pemerintah telah memberikan regulasi-regulasi tersebut, masih banyak pelaku usaha yang membentuk perjanjian tanpa melakukan implementasi UUPK terhadap pencantuman klausula baku. Perjanjian elektronik dengan pencantuman klausula baku ini telah sering dijalankan oleh para pelaku usaha termasuk maskapai-maskapai penerbangan di Indonesia. Salah satu contohnya yaitu dilakukan oleh Sriwijaya Air. Untuk pertama kalinya, maskapai penerbangan di Indonesia menawarkan program layanan penerbangan gratis selama setahun dengan jumlah pembayaran tertentu. Sriwijaya Air meluncurkan program ini dengan nama Sriwijaya Travel Pass (SJ Travel Pass) di Jakarta pada rabu 2 Mei 2018 lalu. Konsumen sebagai pemilik keanggotaan dari SJ Travel Pass dijanjikan untuk dapat menikmati layanan terbang bebas sepuasnya dalam penerbangan domestik selama satu tahun penuh tanpa adanya pembatasan jumlah penerbangan yang akan diambil, hanya dengan melakukan pembayaran sebesar dua belas juta rupiah. Melihat harga tiket penerbangan yang cukup mahal saat ini tentu saja penawaran ini menarik banyak perhatian dari konsumen, terutama para konsumen yang sering melakukan perjalanan menggunakan alat transportasi udara ini.

${ }^{10)}$ Endang Purwaningsih, Hukum Bisnis, (Bogor: Ghalia Indonesia, 2010), 79. 
Volume 2 Nomor 2, Desember 2019

E-ISSN : 2655-7347

Perjanjian SJ Travel Pass dituangkan dalam bentuk perjanjian elektronik pada umumnya. Konsumen tinggal melakukan persetujuan pada perjanjian yang telah dibentuk oleh pelaku usaha. Perjanjian SJ Travel Pass termasuk ke dalam salah satu jenis perjanjian baku, yaitu jenis perjanjian yang mengandung beberapa syarat dan ketentuan atau yang dapat dikatakan dengan sebutan klausula baku. Pencantuman klausula baku dalam suatu perjanjian tidak ditujukan untuk memberikan batasan atau aturan dalam perjanjian sehingga perjanjian tidak perlu dibicarakan lagi untuk mencapai suatu kesepakatan, melainkan kesepakatan antara pelaku usaha dan konsumen hanya berdasarkan persetujuan yang didapatkan dari pihak konsumen saja, prinsipnya seperti jika memang konsumen menyetujui dan merasa tidak akan dirugikan maka silahkan lakukan kesepakatan atas perjanjian tersebut, tetapi jika dirasanya akan mengakibatkan kerugian di kemudian hari, silahkan tinggalkan penawaran kesepakatan perjanjian tersebut.

Dalam pencantuman klausula baku tidak semua klausula baku baik adanya melainkan dapat menimbulkan kerugian bagi pihak-pihak lain. Untuk menghindari efek merugikan bagi pihak lainnya, maka pemerintah membuat aturan secara sistematis mengenai pelarangan penggunaan beberapa klausula baku. Tetapi pada kenyataannya, meskipun telah ada peraturan yang secara tegas mengatur tetap saja para pelaku usaha kerapkali tidak menyesuaikan pencantuman klausula baku sesuai dengan yang seharusnya. Masih banyak perjanjian yang mengandung klausula baku yang tidak sesuai dengan regulasi yang ada sehingga menimbulkan kerugian dalam hubungan hukum antara pelaku usaha dan konsumen.

Kejadian pencantuman klausula baku pada perjanjian yang menyebabkan konsumen mengalami kerugian telah terjadi berulang kali di masyarakat. Dengan dunia modern yang telah memasuki dunia ekonomi digital saat ini, konsumen tidak akan mungkin dapat lagi menghindari pencantuman klausula baku. 
Volume 2 Nomor 2, Desember 2019

E-ISSN : 2655-7347

Tetapi pada kenyataannya dalam perjanjian SJ Travel Pass ini terdapat salah satu klausula baku yang bertentangan dengan Pasal 18 ayat (1) huruf g UUPK, yang menyatakan bahwa: "Pihak Sriwijaya Air memiliki hak untuk melakukan perubahan aturan di kemudian hari." Sehingga pada saat perjanjian berlangsung, pihak Sriwijaya Air melakukan perubahan aturan dalam hal limitasi kuota dan perubahan kelas tiket penerbangan yang menyebabkan konsumen mengalami kerugian. Yang pada mulanya konsumen SJ Travel Pass tidak dibatasi jumlah seats dalam penerbangan tersebut, diubah oleh pihak Sriwjaya Air yang memberikan pengumumang melalui surat elektronik kepada konsumen SJ Travel Pass bahwa konsumen SJ Travel Pass hanya bisa menggunakan seats sebanyak 30\% dalam setiap pesawat penerbangan. Hal ini menimbulkan kerugian karena konsumen kesulitan untuk mendapatkan tiket penerbangan dengan adanya limitasi kuota tersebut bahkan beberapa konsumen tidak mendapatkan hak terbangnya sama sekali selama masa berlangsungnya perjanjian SJ Travel Pass tersebut.

Setelah adanya perubahan aturan perihal limitasi kuota ini, pihak Sriwijaya Air melakukan perubahan aturan kembali dalam perjanjian SJ Travel Pass perihal jenis kelas tiket yang didapatkan oleh pihak konsumen SJ Travel Pass. Mulanya pada saat konsumen melakukan pemesanan tiket melalui keanggotaan SJ Travel Pass mereka, maka konsumen akan mendapatkan tiket ready atau tiket yang dapat digunakan secara langsung untuk penerbangan. Tetapi kemudian pihak Sriwijaya Air melakukan perubahan tiket menjadi tiket standby dimana pada saat konsumen melakukan pembelian tiket penerbangan, maka konsumen tidak dapat langsung terbang melainkan akan mendapatkan kepastian terbang pada saat 60 menit terakhir sebelum penerbangan tersebut melakukan perjalanannya. Konsumen akan dapat melakukan penerbangan apabila masih tersedia seats dalam pesawat penerbangan tersebut.

Padahal salah satu hal yang menjdi pertimbangan dari UUPK ini adalah pembangunan nasional yang dittujukan untuk mewujudkan kehidupan bermasyarakat yang adil dan makmur baik secara materiil dan imateriil dalam 
Volume 2 Nomor 2, Desember 2019

E-ISSN : 2655-7347

era demokrasi ekonomi yang didasarkan pada Pancasila dan Undang-Undang Dasar 1945, oleh karena itu, seharusnya program pembangunan perekonomian nasional harus menjadi faktor pendukung berkembangnya dunia usaha yang menghasilkan beraneka barang dan/atau jasa yang didukung dengan perkembangan teknologi yang dapat meningkatkan kesejahteraan masyarakat luas dengan memberikan kepastian barang dan/atau jasa yang diperoleh dari perdagangan sehingga tidak memberikan kerugian bagi konsumen. ${ }^{11}$

Berdasarkan pemaparan latar belakang di atas, Penulis tertarik untuk mengkaji dan melakukan penelitian terhadap perlindungan konsumen dalam perjanjian SJ Travel Pas, maka diangkatlah judul jurnal ini yaitu: "ANALISIS PENCANTUMAN KLAUSULA BAKU DALAM PERJANJIAN SJ TRAVEL PASS DITINJAU DARI UNDANGUNDANG NOMOR 8 TAHUN 1999 TENTANG PERLINDUNGAN KONSUMEN."

\section{B. Perumusan Masalah}

Berdasarkan uraian yang dikemukakan dalam latar belakang di atas, maka pokok permasalahan yang akan diangkat adalah sebagai berikut:

1. Apakah pencantuman klausula baku pada perjanjian SJ Travel Pass melanggar Pasal 18 Undang-Undang Nomor 8 Tahun 1999 tentang Perlindungan Konsumen?

2. Bagaimana tanggung jawab PT. Sriwijaya Air terhadap pencantuman klausula baku terhadap konsumen?

\section{Metode Penelitian}

Berdasarkan permasalahan yang akan diteliti oleh Penulis, maka Penulis memilih untuk menggunakan jenis penelitian hukum normatif dalam penulisan ini karena menurut Penulis metode ini yang paling sesuai

11) Zaeni Asyihadie, Hukum Bisnis: Prinsip Dan Pelaksanaannya Di Indonesia, (Jakarta: Rajawali Pers, 2012), 191. 
Volume 2 Nomor 2, Desember 2019

E-ISSN : 2655-7347

untuk mengkaji permasalahan terkait. Penelitian dilakukan dengan cara melakukan penelitian atas kaidah atau aturan hukum sebagai suatu sistem yang terkait menggunakan bahan pustaka atau bahan sekunder dengan menggunakan pendekatan peraturan perundang-undangan dan pendekatan konsep dimana penulis menggunakan peraturan perundang-undangan sebagai dasar awal melakukan analisis, dan menjadikannya sebagai titik focus dasar dari penelitian ini sehingga akan memunculkan banyak konsep bagi suatu fakta hukum dan melahirkan pengertian-pengertian, konsepkonsep, dan asas-asas hukum. Dalam penelitian ini Penulis menggunakan bahan hukum primer, sekunder, tersier, dan termasuk juga bahan nonhukum dengan menggunakan teknik pengumpulan data melalui wawancara dengan para pihak terkait dan Akademisi. Setelah pengumpulan bahanbahan terkumpul, selanjutnya bahan-bahan tersebut akan diolah sedemikian rupa oleh Penulis dengan cara melakukan seleksi data sekunder atau bahan hukum dan melakukan klasifikasi menurut penggolongan bahan hukum dan menyusun data hasil penelitian tersebut sehingga bahan dan data tersebut tersusun secara sistematis, tentu saja dilakukan secara logis sehingga ada hubungan dan keterkaitan antara bahan hukum satu dengan bahan hukum lainnya untuk mendapatkan gambaran umum dari hasil penelitian. ${ }^{12)}$

\section{PEMBAHASAN}

\section{A. Kesesuaian Pencantuman Klausula Baku Pada Perjanjian SJ Travel} Pass Dengan Undang-Undang Nomor 8 Tahun 1999 Tentang Perlindungan Konsumen

Pada dasarnya manusia merupakan manusia sebagai makhluk sosial yang artinya manusia tidak dapat hidup sendiri dan membutuhkan orang lain untuk bertahan hidup. Tiap-tiap individu dalam masyarakat memiliki masing-masing kepentingan dimana untuk memenuhi kepentingan tersebut manusia membutuhkan bantuan orang lain, dan pada saat manusia meminta

12) Mukti Fajar ND dan Yulianto Achmad, Dualisme Penelitian Hukum Normatif \& Empiris, (Yogyakarta: Pustaka Pelajar, 2010), 181. 
Volume 2 Nomor 2, Desember 2019

E-ISSN : 2655-7347

bantuan orang lain untuk membantunya maka hadirlah dengan apa yang biasa kita sebut dengan perjanjian. Ketika seseorang memberikan tawaran kepada seseorang lainnya untuk membantunya mencapai kepentingan tersebut dengan memberikan imbalan yang diinginkan pihak lain, disinilah kesepakatan untuk membuat suatu perjanjian hadir. Maka dalam kehidupan bermasyarakat tidak mungkin seseorang dapat menghindari sebuah perjanjian.

Salah satu perjanjian yang sering terjadi dalam masyarakat yaitu perjanjian antara pelaku usaha dan konsumen. Karena pada hakikatnya setiap orang memiliki kepentingan untuk memenuhi kebutuhan hidupnya dan tidak semua kebutuhannya dapat ia produksi sehingga akan membutuhkan bantuan orang lain untuk memenuhi kebutuhannya. Pada era ekonomi digital, perjanjian yang diadakan pada umumnya berupa perjanjian elektronik, dimana para pihak tidak saling bertemu melainkan perjanjian hanya dilakukan dengan perantara internet. telah banyak dilakukan perjanjian elektronik. Sehingga pada umumnya untuk mempermudah terbentuknya perjanjian pelaku usaha akan mencantumkan klausulaklausula baku untuk memberikan batasan-batasan atau aturan-aturan tambahan dalam perjanjian.

Artinya perjanjian akan secara langsung terbentuk pada saat itu juga saat telah adanya kesepakatan dari para pihak. Ketika para pihak telah mencapai kesepakatan tanpa perlu melakukan kewajiban, tanpa perlu melakukan perjanjian secara tertulis, atau hal-hal lainnya, perjanjian telah ada saat itu juga hanya dengan berdasarkan tanda atau gerakan persetujuan dari para pihak seperti berjabat tangan, perkataan setuju, anggukan kepala, dan lain-lain.

Dalam era globalisasi ini, pelaku usaha umumnya melakukan perdagangan produk dan/atau jasa dalam masyarakat memanfaatkan fasilitas internet seperti website, platform digital, e-commerce, dan lain-lain. Pelaku usaha akan memberikann penawarannya dalam bentuk seperti formulir, pemberian opsi-opsi yang dapat ditentukan oleh konsumen secara 
Volume 2 Nomor 2, Desember 2019

E-ISSN : 2655-7347

langsung, atau bentuk lainnya sehingga konsumen dapat melakukan transaksi pada waktu yang diinginkan oleh konsumen. Ketika konsumen melakukan persetujuan atas transaksi tersebut maka saat itu juga akn terbentuk perjanjian yang akan menimbulkan hubungan hukum yang sah diantara pihak konsumen dengan pihak pelaku usaha.

Dalam hubungan hukum di antara pihak pelaku usaha dan pihak konsumen akan timbul hak dan kewajiban terhadap tiap-tiap pihak yang bersifat mengikat para pihak karena adanya perjanjian. Mernurut prinsip the privity of contract dalam hubungan hukum, pihak pelaku usaha memiliki kewajiban untuk memberikan perlindungan kepada konsumen yang menuntut agar pihak pelaku usaha memenuhi hak-hak konsumen sebagaimana yang telah ia perjanjikan dalam perjanjian dan apabila pelaku usaha tidak melakukan kewajibannya maka konsumen berhak melakukan gugatan kepada pelaku usaha atas dasar wanprestasi. ${ }^{13)}$

Perjanjian elektronik dengan pencantuman klausula baku yang akan Penulis teliti seperti yang telah disebutkan pada sebelumnya, yaitu perjanjian SJ Travel Pass yang dibentuk antara pihak Sriwijaya Air sebagai pihak pelaku usaha dengan anggota SJ Travel Pass sebagai pihak konsumen. SJ Travel Pass merupakan program pertama yang diluncurkan di Indonesia dengan memberikan penerbangan gratis ke seluruh tujuan domestic selama setahun hanya dengan membayar Rp.12.000.000.00 (dau belas juta rupiah). Sriwijaya Air menjadi pelopor yang mencetuskan program ini perama kali di Indonesia. Menurut Penulis, apabila dilihat dari sisi persaingan usaha antar maskapai penerbangan, program ini dapat menjadi suatu inovasi yang bagus dan mengandung ide yang kreatif. Pada awal peluncuran program, dapat dikatakan Sriwijaya Air mengalami kesuksesan karena dapat menarik perhatian konsumen sehingga Sriwijaya dapat memenangkan persaingan usaha di era modern ini. Sehingga program ini dapat dijadikan sebagai

\footnotetext{
13) Shidarta, Hukum Perlindungan Konsumen Indonesia, (Jakarta: Grasindo, 2000), 4.
} 
Volume 2 Nomor 2, Desember 2019

E-ISSN : 2655-7347

contoh atau acuan bagi maskapai penerbangan lainnya apabila program ini berjalan dengan lancar.

Penulis menganalisa Pasal 1313 KUHPer dengan Perjanjian SJ Travel Pass dan berpendapat bahwa, perjanjian SJ Travel Pass langsung terbentuk secara sah pada saat konsumen melakukan persetujuan terhadap perjanjian tersebut, karena pada detik itu pula artinya penawaran dari pihak pelaku usaha bertemu dengan kesepakatan yang diberikan oleh pihak konsumen meskipun konsumen belum melaksanakan kewajibannya yaitu melakukan pembayaran yang seharusnya. Sehingga sejak saat itu juga tercipta hubungan hukum antara Sriwijaya Air dengan konsumen yang bersifat mengikat para pihak atas hak dan kewajibannya.

Sebagaimana telah dibahas, suatu perjanjian dapat terjadi karena adanya suatu kesepakatan. Suatu kesepakatan memungkinkan terjadi dengan didasarkan pada kehendak seseorang untuk melakukan suatu perjanjian yang dikehendaki. Mengacu kepada Pasal 1338 ayat (1) KUHPer, Indonesia merupakan salah satu negara yang melakukan implementasi asas kebebasan berkontrak artinya setiap orang memiliki kebebasan untuk melakukan perjanjian dengan siapapun mengenai hal apapun yang dikehendakinya.

Penulis menganalisa kembali asas kebebasan berkontrak dengan proses terjadinya perjanjian SJ Travel Pass dan Penulis berpendapat bahwa pada perjanjian SJ Travel Pass telah sesuai dengan asas kebebasan berkontrak karena pihak konsumen memiliki kehendak untuk melakukan perjanjian dengan pihak Sriwijaya Air tanpa mendapatkan paksaan dari pihak manapun. Sehingga dari kehendak tersebut maka terjadilah kata sepakat hingga terbentuklah perjanjian SJ Travel Pass. Tetapi menurut Penulis apabila kita melihat isi perjanjian SJ Travel Pass secara menyeluruh bukan hanya dari sisi proses terbentuknya melainkan juga melihat isi dari perjanjian SJ Travel Pass yang mencantumkan klausula baku, menurut Penulis asas kebebasan berkontrak pada perjanjian ini tidak dapat dikatakan sebagai kebebasan yang mutlak lagi melainkan kebebasan ini menjadi 
Volume 2 Nomor 2, Desember 2019

E-ISSN : 2655-7347

terbatas karena adanya klausula baku dalam perjanjian. Klausula baku dalam perjanjian ini dapat menyebabkan ketidakseimbangan kedudukan kedua belah pihak, klausula baku memberikan keuntungan bagi pihak pembuat klausula baku sehingga kedudukannya menjadi lebih tinggi. Sehingga asas kebebasan berkontrak pada perjanjian SJ Travel Pass ini hanya sebatas dengan keinginan konsumen untuk melakukan persetujuan perjanjian yang telah disediakan oleh pihak Sriwijaya Air.

Sebagai badan hukum, maskapai penerbangan Sriwijaya Air merupakan subyek hukum yang dapat melakukan tindakan hukum termasuk membentuk perjanjian dengan konsumen dan secara sah dapat melakukan perdagangan jasa penerbangan di masyarakat. Yang dimaksudkan sebagai perjanjian dalam dunia maskapai penerbangan ialah: ${ }^{14)}$

"perjanjian antara pengangkut dan pihak penumpang dan/atau pengirim kargo untuk mengangkut penumpang dan/atau kargo dengan pesawat udara, dengan imbalan bayaran atau dalam bentuk imbalan jasa yang lain."

Berdasarkan pada pendefinisian perjanjian pengangkutan udara tersebut, jika melihat unsur-unsur yang ada pada perjanjian pengangkutan udara dan membandingkan kembali dengan unsur-unsur yang ada pada perjanjian SJ Travel Pass maka menurut Penulis unsur-unsur tersebut yaitu:

1. Dilakukan antara pengangkut dan pihak penumpang, yang mana pada perjanjian SJ Travel Pass perjanjian ini telah sesuai dengan unsur yang ada karena perjanjian dilakukan oleh Sriwijaya Air sebagai pengangkut dan konsumen yang menjadi anggota SJ Travel Pass sebagai penumpang.

2. Pengangkut menjanjikan untuk mengangkut penumpang dengan pesawat udara, yang dalam perjanjian SJ Travel Pass pihak Sriwijaya Air menjanjikan untuk memberikan layanan penerbangan kepada konsumennya menggunakan pesawat penerbangan NAM Air dan Sriwijaya Air.

14) Indonesia, Undang-Undang Nomor 1 Tahun 2009 tentang Penerbangan Pasal 1 angka 29. 
Volume 2 Nomor 2, Desember 2019

E-ISSN : 2655-7347

3. Konsumen memberikan imbalan bayaran atau dalam bentuk imbalan lainnya, dalam perjanjian SJ Travel Pass pihak konsumen memberikan imbalan dalam bentuk pembayaran sebesar Rp.12.000.000.- (dua belas juta rupiah) atas jasa pelayanan yang diberikan oleh pihak Sriwijaya Air selama setahun untuk seluruh penerbangan domestik.

Penulis berpendapat bahwa perjanjian SJ Travel Pass telah sesuai dengan unsur-unsur dari definisi perjanjian pengangkutan udara, maka dapat dikatakan bahwa perjanjian SJ Travel Pass merupakan perjanjian sah yang telah sesuai dengan apa yang dimaksud dengan perjanjian pengangkutan udara. Maka perjanjian SJ Travel Pass akan berlaku sebagaimana perjanjian umumnya yang menimbulkan hubungan hukum dengan hak dan kewajiban yang mengikat para pihak dalam perjanjian tersebut.

Mengacu kepada syarat-syarat sahnya perjanjian dalam Pasal 1320 KUHPer, Penulis akan menguraikan dan melakukan analisa ke dalam perjanjian SJ Travel Pass. Melalui syarat pertama dapat kita simpulkan bahwa perjanjian akan sah apabila sudah tercapai kata sepakat dan bersedia untuk tunduk kepada perjanjian tersebut. Penulis berpendapat bahwa SJ Travel Pass telah memenuhi syarat kesepakatan para pihak. Hal ini terlihat pada awal mula pihak pelaku usaha telah memberikan formulir perjanjian dan konsumen telah melakukan persetujuan atas isi perjanjian tersebut yang dapat diartikan bahwa antara pihak pelaku usaha dan pihak konsumen telah mencapai suatu kesepakatan dalam bentuk perjanjian elektronik. Persetujuan atas perjanjian elektronik ini tetap berlaku secara sah layaknya perjanjian umumnya sebagaimana diatur dalam UU ITE.

Melalui persyaratan kedua, perihal kecakapan para pihak dalam membuat perjanjian. Melalui pasal 1329 KUHPer yang menyatakan bahwa "Tiap orang berwenang untuk membuat perikatan, kecuali jika ia dinyatakan tidak cakap untuk hal itu." Pada dasarnya semua subyek hukum cakap untuk melakukan perjanjian tiada satu subyek hukum pun yang tidak diperbolehkan untuk melakukan perjanjian, kecuali yang telah dianggap 
Volume 2 Nomor 2, Desember 2019

E-ISSN : 2655-7347

tidak cakap oleh undang-undang. Secara umum subyek hukum yang dianggap tidak cakap hukum oleh undang-undang ialah anak-anak dan orang-orang dibawah pengampuan.

Dalam perjanjian SJ Travel Pass, telah dicantumkan dalam syarat dan ketentuan bahwa yang dapat mengikuti program penawaran ini hanyalah orang-orang yang berumur diatas 13 tahun, anak-anak tidak dapat mengikuti program ini. Dengan kata lain, artinya konsumen yang mengadakan perjanjian SJ Travel Pass merupakan orang dewasa. Sehingga dapat disimpulkan bahwa perjanjian SJ Travel Pass telah sesuai dan memenuhi syarat kedua dari Pasal 1320 KUHPer ini.

Syarat ketiga yaitu mengenai suatu hal tertentu, syarat ini mengacu kepada Pasal 1333 KUHPerdata. Yang dimaksudkan melalui syarat ini adalah dalam perjanjian tersebut harus ditentukan pula jenis barang atau jasa yang diperjanjikan dalam perjanjian ini. Obyek yang ada dalam perjanjian ini harus dapat ditentukan baik dari jumlah, ukuran, letak, jenis, harga, meskipun pada saat perjanjian dibentuk obyek masih belum ada. Menurut Penulis dalam perjanjian SJ Travel Pass, sudah secara jelas ditentukan mengenai hal yang menjadi obyek yang akan diperjanjikan dalam perjanjian ini yaitu jasa Sriwijaya Air untuk memberikan penerbangan gratis selama setahun ke seluruh penerbangan domestik kepada konsumen yang telah melakukan pembayaran sebesar Rp.12.000.000.- kepada pihak Sriwijaya Air. Sehingga Penulis berpendapat bahwa syarat ketiga ini telah terpenuhi dalam perjanjian SJ Travel Pass ini.

Syarat keempat ini merupakan sebab yang halal. Sistem hukum perjanjian di Indonesia memang bersifat terbuka yang artinya memberikan kebebasan kepada para pihak seluas-luasnya untuk mengadakan perjanjian dengan isi apapun dengan syarat tidak boleh bertentangan dengan undangundang, asas, ataupun ketentuan umum. Jika bertentangan dengan hal-hal tersebut, maka perjanjian akan dianggap terbentuk dengan alasan yang tidak halal sehingga perjanjian tersebut menjadi tidak sah. Penulis menganalisa syarat keempat ini dan beranggapan bahwa perjanjian SJ Travel Pass 
Volume 2 Nomor 2, Desember 2019

E-ISSN : 2655-7347

tidaklah memenuhi syarat tersebut. Hal ini disebabkan karena dalam perjanjian SJ Travel Pass terkandung klausula baku yang bertentangan dengan undang-undang sehingga syarat sebab yang halal tidak terpenuhi.

Maka menurut Penulis dikarenakan Pasal 1320 KUHPer tidak terpenuhi oleh perjanjian SJ Travel Pass, maka dapat dikatakan bahwa perjanjian SJ Travel Pass tidak dapat dikatakan sebagai perjanjian yang sah.

Penulis berpendapat bahwa perjanjian SJ Travel Pass dibentuk antara pihak konsumen dengan pihak pelaku usaha yang dinaungi dengan payung hukum UUPK. Pada umumnya perjanjian yang dibentuk antara pelaku usaha dan konsumen merupakan perjanjian berbentuk perjanjian baku, yang artinya isi dalam perjanjian tersebut telah ditentukan isinya oleh pihak pelaku usaha terlebih dahulu sehingga konsumen hanya perlu melakukan persetujuan saja. Aturan, ketentuan, syarat, atau isi yang ditentukan terlebih dahulu oleh pihak pelaku usaha dalam perjanjian inilah kita sebut dengan klausula baku. ${ }^{15)}$ Mengenai pencantuman klausula baku dalam suatu perjanjian bukanlah sebuah tindakan yang dilarang tetapi pemerintah telah memberikan aturan secara sistematis melalui UUPK agar pelaku usaha tidak mencantumkan beberapa klausula baku yang dianggap akan menimbulkan kerugian bagi konsumen.

Pelaku usaha dalam melakukan pencantuman klausula baku pada perjanjian dilarang membuat klausula baku yang: ${ }^{16)}$

1. Menyatakan pengalihan tanggung jawab pelaku usaha;

2. Menyatakan bahwa pelaku usaha berhak menolak penyerahan kembali barang yang dibeli konsumen;

3. Menyatakan bahwa pelaku usaha berhak menolak penyerahan kembali uang yang dibayarkan atas barang dan/atau jasa yang dibeli oleh konsumen;

15) Indonesia, Undang-Undang Nomor 8 Tahun 1999 tentang Perlindungan Konsumen, Pasal 1 angka 10.

16) Ibid., Pasal 18 ayat (1). 
Volume 2 Nomor 2, Desember 2019

E-ISSN : 2655-7347

4. Menyatakan pemberian kuasa dari konsumen kepada segala pelaku usaha baik secara langsung maupun tidak langsung untuk melakukan segala tindakan sepihak yang berkaitan dengan barang yang dibeli oleh konsumen secara angsuran;

5. Mengatur perihal pembuktian atas hilangnya kegunaan barang atau pemanfaatan jasa yang dibeli oleh konsumen;

6. Memberi hak kepada pelaku usaha untuk mengurangi manfaat jasa atau mengurangi harta kekayaan konsumen yang menjadi obyek jual beli jasa;

7. Menyatakan tunduknya konsumen kepada peraturan yang berupa aturan baru, tambahan, lanjutan dan/atau pengubahan lanjutan yang dibuat sepihak oleh pelaku usaha dalam masa konsumen memanfaatkan jasa yang dibelinya; dan

8. Menyatakan bahwa konsumen memberi kuasa kepada pelaku usaha untuk pembebanan hak tanggungan, hak gadai, atau hak jaminan terhadap barang yang dibeli oleh konsumen secara angsuran."

Dalam perjanjian SJ Travel Pass ada beberapa pencantuman klausula baku yang disebut sebagai syarat dan ketentuan, salah satu isi dari klausula baku tersebut yaitu:

"Pihak Sriwijaya Air memiliki hak untuk mengubah peraturan di kemudian hari."

Maka Penulis melakukan analisis terhadap klausula baku pada perjanjian SJ Travel Pass tersebut dengan Pasal 18 ayat (1) huruf g yang mengatur tentang larangan dalam pencantuman klausula baku, dan menarik kesimpulan bahwa klausula baku yang tercantum dalam perjanjian SJ Travel Pass tersebut tidaklah sesuai atau bertentangan dengan regulasi yang ada.

Melalui klausula baku tersebut dinyatakan bahwa pihak Sriwijaya Air memiliki hak untuk melakukan perubahan-perubahan aturan tertentu secara sepihak selama proses berlangsungnya perjanjian SJ Travel Pass dan konsumen berkewajiban untuk mematuhi perubahan aturan tersebut. Pada kenyataannya, Sriwijaya Air dalam perjanjian SJ Travel pass menggunakan klausula baku tersebut untuk melakukan perubahan aturan. Perubahan- 
Volume 2 Nomor 2, Desember 2019

E-ISSN : 2655-7347

perubahan aturan yang dilakukan oleh pihak Sriwijaya antara lain ada dua yaitu limitasi kuota dan perubahan kelas tiket penerbangan.

Perubahan mengenai limitasi kuota yang dilakukan oleh Sriwijaya Air pada tanggal 22 Oktober 2018, yaitu pada awal perjanjian konsumen berhak mendapatkan kursi dalam pesawat penerbangan selama persediaan kursi masih ada, hal ini berubah dengan adanya peraturan limitasi kuota yang dibuat oleh Sriwijaya Air. Dalam suatu pesawat penerbangan, konsumen SJ Travel Pass hanya dapat menggunakan sejumlah kursi dalam pesawat sebagaimana ditentukan oleh Sriwijaya Air meskipun masih ada kursi kosong dalam penerbangan selain yang telah ditentukan oleh pihak Sriwijaya Air, jumlah alokasi kursi yang dilakukan oleh Sriwijaya Air yaitu:

1. Pada pesawat Boeing 737-800 atau 737-900 konsumen SJ Travel Pass akan mendapatkan 75 seats dari 189-220 seats.

2. Pada pesawat Boeing 737-300 atau 737-500 konsumen SJ Travel Pass akan mendapatkan 112-148 seats.

3. Pada peawat ATR 72-600 konsumen SJ Travel Pass akan mendapatkan 15 seats dari 72 seats.

Dimana hal ini menyebabkan konsumen SJ Travel Pass menjadi sering tidak dapat melakukan pembelian tiket, padahal masih banyak kursi kosong pada pesawat penerbangan tersebut. Sehingga konsumen SJ Travel Pass merasa dirugikan dengan adanya peraturan baru ini.

Mengenai perubahan aturan perihal tiket yang didapatkan oleh konsumen oleh Sriwijaya Air, pada awal perjanjian konsumen yang melakukan pembelian tiket penerbangan akan mendapatkan tiket kelas $\mathrm{F}$ berubah menjadi tiket kelas A. Tiket kelas F merupakan tiket yang bisa digunakan langsung untuk melakukan penerbangan, sedangkan tiket kelas A sama artinya dengan tiket standby. Dalam kasus tiket standby ini artinya konsumen akan mendapatkan kepastian bahwa ia dapat melakukan perjalanan penerbangan pada saat 60 menit sebelum penerbangan berlangsung.

Menurut Penulis, aturan-aturan baru yang dibentuk oleh pihak Sriwijaya Air menyebabkan ketidakadilan bagi konsumen, konsumen tidak 
Volume 2 Nomor 2, Desember 2019

E-ISSN : 2655-7347

mendapatkan hak-hak yang seharusnya sebagaimana diperjanjikan pada awal mula perjanjian dibentuk. Padahal pada dasarnya perjanjian SJ Travel Pass terbentuk karena konsumen setuju atas penawaran yang dilakukan ditawarkan oleh Sriwijaya Air dan karena adanya klausula baku tersebut dalam proses keberlangsungannya konsumen tidak mendapatkan hak-haknya.

Pada perjanjian SJ Travel Pass Sriwijaya Air merupakan pelaku usaha yang memperdagangkan jasa di masyarakat, artinya Sriwijaya Air memasarkan suatu layanan penerbangan untuk dimanfaatkan oleh konsumen. Yang mana dalam permasalahan ini transaksi perdagangan Sriwijaya Air dengan konsumen dilandasi oleh perjanjian SJ Travel Pass yang telah disepakati sebelumnya. Apabila dilihat kembali dari awal mula perjanjian SJ Travel Pass hingga tindakan-tindakan yang dilakukan oleh Sriwijaya Air sampai dampak kerugian yang dialami oleh konsumen, Penulis menyimpulkan bahwa Sriwijaya Air dapat dikatakan telah melakukan wanprestasi karena telah melakukan hal-hal yang seharusnya tidak dilakukan, dan tidak memenuhi hal-hal yang diperjanjikan pada perjanjian. Tetapi bila Penulis melihat dari awal mula terbentuk perjanjian SJ Travel Pass maka Penulis berpendapat bahwa tindakan Sriwijaya Air ini juga dapat dikatakan sebagai perbuatan melawan hukum. Untuk dikatakan bahwa Sriwijaya Air melakukan perbuatan melawan hukum maka harus memenuhi unsur-unsur perbuatan melawan hukum sebagaimana tercantum dalam Pasal 1365 yaitu: "Tiap perbuatan melanggar hukum, yang membawa kerugian kepada orang lain, mewajibkan orang yang karena salahnya menerbitkan kerugian itu, mengganti kerugian tersebut."

\section{B. Tanggung Jawab Pihak PT. Sriwijaya Air Dalam Pencantuman}

\section{Klausula Baku Pada Perjanjian SJ Travel Pass}

Menurut Penulis perbuatan Sriwijaya Air dalam melakukan pencantuman klausula baku dalam perjanjian SJ Travel Pass telah memenuhi unsur melanggar hukum karena pencantuman tersebut telah melanggar regulasi yaitu UUPK, maka dapat dikatakan terpenuhilah unsur pertama 
Volume 2 Nomor 2, Desember 2019

E-ISSN : 2655-7347

tersebut. Dimana perbuatan pada unsur pertama ini menyebabkan unsur kedua dari perbuatan melanggar hukum pun terpenuhi. Karena dengan Sriwijaya melakukan tindakan tersebut menyebabkan konsumen mengalami kerugian. Sehingga berdasarkan tindakan-tindakannya tersebut tentunya pihak Sriwijaya Air memiliki kewajiban untuk melakukan ganti rugi atas kerugian konsumen.

Menurut Penulis dilihat dari prinsip tanggung jawab menurut UUPK, maka Sriwijaya Air memiliki tanggung jawab profesional kepada konsumen SJ Travel Pass. Hal ini dikarenakan yang diperdagangkan oleh pihak Sriwijaya Air merupakan jasa profesionalnya sebagai perusahaan maskapai penerbangan. Dari klasifikasi jasa, pelayanan yang diberikan oleh pihak Sriwijaya Air merupakan jasa yang dapat dihitung hal ini dikarenakan pelayanan jasa penerbangan yang dilakukan Sriwijaya Air dapat dijalankan dengan memiliki perhitungan yang pasti.

Tanggung jawab pelaku usaha dalam UUPK diatur secara sistematis melalui Pasal 19, yang menjelaskan bahwa:

1. Pelaku usaha bertanggung jawab memberikan ganti rugi atas kerusakan, pencemaran, dan/atau kerugian konsumen akibat mengkonsumsi barang dan/atau jasa yang dihasilkan atau diperdagangkan

2. Ganti rugi dapat berupa pengembalian uang atau penggantian barang/dana tau jasa yang sejenis atau setara nilainya, atau perawatan kesehatan dan/atau pemberian santunan yang sesuai dengan ketentuan peraturan perundang-undangan yang berlaku.

Mengacu kepada Pasal 19 UUPK tersebut, Penulis berpendapat bahwa dalam permasalahan SJ Travel Pass Sriwijaya diharuskan melakukan tanggung jawab atas tindakannya dengan memberikan ganti rugi kepada konsumen SJ Travel Pass yang mengalami kerugian dengan bentuk:

1. Memberikan perpanjangan masa keanggotaan SJ Travel Pass sebagai bentuk ganti rugi konsumen yang tidak dapat melakukan pemesanan selama 3 bulan karena adanya perbaikan sistem dari Sriwijaya Air. 
Volume 2 Nomor 2, Desember 2019

E-ISSN : 2655-7347

2. Memberikan uang pengembalian seharga pembayaran SJ Travel Pass kepada konsumen yang selama masa perjanjian SJ Travel Pass tidak dapat melakukan pembelian tiket penerbangan karena adanya perubahan perubahan aturan dari pihak Sriwijaya Air.

3. Mencabut klausula baku yang bertentangan dengan UUPK pada perjanjian SJ Travel Pass dan mengembalikan aturan-aturan yang ada pada SJ Travel Pass seperti pada awal mula perjanjian dibentuk.

\section{PENUTUP}

\section{A. Kesimpulan}

Berdasarkan analisis pembahasan yang telah Penulis lakukan, maka Penulis menarik kesimpulan terkait permasalahan yang diangkat, yakni:

1. Dasar hukum dari terbentuknya perjanjian SJ Travel Pass ada 5 (lima) instrumen hukum yaitu KUHPer, UUPK, UU ITE, UU Penerbangan, dan PM TJAUP. Dalam perihal pencantuman klausula baku pada perjanjian SJ Travel Pass yang dilakukan oleh Pihak Sriwijaya Air tidak sesuai dengan regulasi yang berlaku di Indonesia yang mengatur tentang pencantuman klausula baku dalam perjanjian yaitu UUPK.

2. Pada prinsipnya, pihak Sriwijaya Air melakukan perbuatan melawan hukum karena telah melanggar Pasal 18 ayat (1) huruf g UUPK perihal pencantuman klausula baku yang dilarang dan perbuatan ini menyebabkan kerugian bagi pihak konsumen sehingga konsumen dapat melakukan gugatan kepada Sriwijaya Air atas kerugian yang dialaminya. Pihak Sriwijaya Air memiliki kewajiban untuk melakukan tanggung jawab atas tindakannya dan memberikan ganti rugi kepada konsumen.

\section{B. Saran}

Berdasarkan kesimpulan di atas, adapun saran yang akan diberikan Penulis dalam penelitian ini adalah:

1. Untuk mengurangi permasalahan konsumen terutama kerugiankerugian yang dialami oleh konsumen akibat klausula baku dalam 
Volume 2 Nomor 2, Desember 2019

E-ISSN : 2655-7347

perjanjian yang tidak sesuai dengan regulasi yang ada, kosumen diharapakan dapat lebih teliti, cermat, dan membaca isi perjanjian secara keseluruhan sebelum melakukan persetujuan pada perjanjian sehingga dapat menghindar dari adanya klausula-klausula yang mungkin memberikan kerugian di kemudian hari.

2. Guna mengurangi kecurangan pencantuman klausula baku yang dilakukan oleh pelaku usaha dalam mengadakan perjanjian dengan konsumen, Pemerintah diharapkan dapat memperbaharui peraturan perundang-undangan sehingga payung hukum dapat berjalan secara seimbang dengan perkembangan-perkembangan yang terjadi di era ekonomi digital ini dan Pemerintah diharapkan dapat melakukan pengawasan yang lebih ketat terhadap transaksi-transaksi bisnis yang terjadi.

\section{DAFTAR PUSTAKA}

\section{A. Buku}

Asyhadie, Zaeni. Hukum Bisnis: Prinsip Dan Pelaksanaannya Di Indonesia. Jakarta: Rajawali Pers, 2012.

Jinca, M.Y. Transportasi Laut Indonesia: Analisis Sistem \& Studi Kasus. Surabaya: Brilian Internasional, 2011.

ND, Mukti Fajar dan Yulianto Achmad. Dualisme Penelitian Hukum Normatif \& Empiris. Yogyakarta: Pustaka Pelajar. 2010.

Purwaningsih, Endang. Hukum Bisnis. Bogor: Ghalia Indonesia, 2010.

Shidarta. Hukum Perlindungan Konsumen Indonesia. Jakarta: Grasindo, 2000.

\section{B. Peraturan Perundang-Undangan}

Kitab Undang-Undang Hukum Perdata.

Indonesia. Undang-Undang Republik Indonesia Nomor 8 Tahun 1999 tentang Perlindungan Konsumen.

. Undang-Undang Republik Indonesia Nomor 1 Tahun 2009 tentang Penerbangan. 
Volume 2 Nomor 2, Desember 2019

E-ISSN : 2655-7347

\section{Jurnal}

Halim, Stefani Erlina dan Siti Nurbaiti. "Perlindungan Hukum Terhadap Transportasi Berbasis Online Yang Menggunakan Driver Cadangan.” Jurnal Adigama. Volume 1, Nomor 2 (Oktober 2018): 3.

\section{Website}

Anung Ade. "Sejarah Dan Perkembangan Angkutan Umum Di Dunia". http://dishub.jabarprov.go.id/artikel/view/309.html. Diakses tanggal 7 Agustus 2019.

Azanella Luthfia Ayu. "Berpergian Dengan Pesawat Disebut Paling Aman: Ini Datanya”. https://internasional.kompas.com/read/2019/03/11/20212381/berp ergian-dengan-pesawat-disebut-paling-aman-inidatanya?page=all. Diakses tanggal 7 Oktober 2019.

Bandara Soekarno-Hatta. "Daftar nama Maskapai Penerbangan Yang Beroperasi Di Indonesia". https://bandarasoekarnohatta.com/daftar-nama-maskapaipenerbangan-yang-beroperasi-di-indonesia.info. Diakses tanggal 7 Oktober 2019.

Menteri Komunikasi Dan Informatika. "Indonesia Akan Jadi Pemain Ekonomi Digital Terbesar Di Asia Tenggara”. https://kominfo.go.id/index.php/content/detail/6441/Indonesia+A kan+Jadi+Pemain+Ekonomi+Digital+Terbesar+di+Asia+Tenggar a/0/berita_satker/. Diakses tanggal 7 Oktober 2019.

Jayani Dwi Hadya. “Jumlah Penduduk Indonesia 269 Juta Jiwa: Terbesar Keempat Di Dunia”. http://databoks.katadata.co.id/datapublish/2019//04/29/jumlahpenduduk-indonesia-269-juta-jiwa-terbesar-keempat-dunia.

Diakses 8 Agustus 2019. 
Volume 2 Nomor 2, Desember 2019

E-ISSN : 2655-7347

Yuniarti Siti. "Internet Dan Ekonomi Digital". https://businesslaw.binus.ac.id/2019/08/26/internet-dan-ekonomi-digital/.

Diakses 21 Desember 2019. 